\title{
SOME INFILTRATION CAPACITY UNIT OF LAND IN MANADO STATE UNIVERSITY AS LECTURES REFERENCES
}

\author{
Novita Sari Mamonto ${ }^{1}$ Jovialine A. Rungkat ${ }^{2}$ Christophil S. Medellu ${ }^{3}$ \\ ${ }^{1}$ Student Department of Natural Science Education, Manado State University. Indonesia \\ ${ }^{2}$ Department of Natural Sciences Education, Manado State University. Indonesia \\ ${ }^{3}$ Department of Physics Education, Manado State University. Indonesia.
}

\begin{abstract}
This study aims to 1) explore concepts and processes of the science of infiltration in a place that varies (slope and vegetation plants) at UNIMA 2) designing concepts and processes of the science of infiltration as lecture references. This study was carried out in June 2019 at the land of the State University of Manado. This study uses explorative research. The results of a measurement of infiltration are the land that has slope $10^{\circ}$ and dampness $20 \%$ as well as in the dominance of grass has the highest rate of infiltration whereas the land that has the texture of the solid land (clay) and nothing plants has the lowest rate of infiltration. Exploring facts in the infiltration can be connected with concepts and processes of science in the form of a matrix. Designing concepts and process science of infiltration such as the material relating to infiltration, the description of the concepts of science on infiltration, and using 3 procedures of explorative in worksheets as a reference in learning processes and practical work in land science courses. The conclusions are concepts and process science of infiltration of covering physics (gravitation, capillarity, the collision on the ground, the mass of raindrops, the mass of the land, the intensity of light, free fall, the dampness of the land), chemistry (the content of rainwater chemicals, heat energy, soil $\mathrm{pH}$ ), biology (evaporation, kinds of roots, hydrology). It can be in the form of a matrix as well as design concepts and process science of infiltration such as material and worksheets as lecture references inland science courses.
\end{abstract}

Keywords - Capacity of infiltration, explorative, concepts and process of science, lecture references

\section{INTRODUCTION}

Land is an area on the surface of the earth's land surface that has its characteristics both of a fairly solid nature and which can be predicted to be recycled, from the biosphere, atmosphere, geology, soil, hydrology and animal and plant populations, as well as the results of human activities in the past and present, insofar as these identifiers exert influence on mankind on land use by humans in the present and the future, (FAO 1977 in Notohadiprawirio, 2006). According to FAO
(1995) quoted by Djayanegara A (2013) in Fitriani (2016), the land has many functions, one of which is a hydrological function.

Hydrology is the study of the occurrence, movement of water and distribution on the earth, both above and below the earth's surface, about the physical, chemical nature of water and its reaction to the environment and relationships with life (Joyce Marta and Wanny Adidarma 1978 in Sulastriningsi, 2011). The existence of water on earth follows a natural law called the hydrological cycle. The hydrological cycle is a term used to describe the circulation of water in three phases (gas, liquid, and solid) that exist on earth. The part of the hydrological cycle is infiltration.

Irawan (2016) states that infiltration is the movement of water down through the surface of the soil into the soil profile. Infiltration causes water to be available for plant growth and groundwater to be replenished. This process is a very important part of the hydrological cycle that can affect the amount of water that is on the surface of the land, where the water that is on the surface of the soil will enter the soil and then flow into the river.

The study of infiltration is important for students to find out how to preserve the surrounding environment and how the infiltration process takes place so that water supply for living things will continue to be fulfilled and rainwater infiltration into the ground at higher altitudes to minimize accumulation of inundation (amounts). in the lower regions, so when the dry season does not occur drought and when the rainy season is not flooded. The land is maintained sustainably so that the absorption of rain can be adequate and the source of clean water for living creatures remains sufficient.

The study was conducted in the Manado State University (UNIMA) environment where there is a lecture process in it. Also, UNIMA is known as a green campus that has 270 hectares of land (Sondakh et al 2015). H acyl observation made by researchers that land of UNIMA there are still many biotic and abiotic components. The use of UNIMA land as a reference in lectures on campus is still lacking because teachers tend to use textbooks that exist. F deed-the fact that there are around still very rare for exploring and design into 


\section{International Journal of Engineering Applied Sciences and Technology, 2020 \\ Vol. 4, Issue 9, ISSN No. 2455-2143, Pages 435-443 \\ Published Online January 2020 in IJEAST (http://www.ijeast.com)}

the concept and process of science as a reference to the first special lecture on the infiltration process.

\section{METHOD}

The type of research used in this research is exploratory research. Explorative research in this study aims to search for facts and phenomena in the natural environment to be appointed as scientific concepts to be used as lecture material. According to Kotler, et al. 2006 in Jaedun 2018) said that explorative research is one of the research approaches used to examine something (which attracts attention) that is not yet known, not yet understood, or not well known.

This research was carried out in June 2019 on the land of Manado State University (UNIMA) on land (Location 1: sloping land with many trees), (location 2: sloping land with fewer trees), (Location 3: flat land with many trees), (location 4: flat land with less trees).

\section{A. Explorative Research Procedure in the Infiltration Process}

This research procedure uses an exploratory research procedure in which there are 3 procedures according to (Medellu \& Silangen 2019), namely:

1. Observation and Identification of Phenomenon Facts and the Relationship Between Objects and Phenomenon Facts

2. Analyze Facts and Phenomena

3. Explore Science Concepts and Processes.

1) Observing the details of the phenomenon of components that interact to affect the phenomenon.

2) Identifying variables that influence phenomena and relationships between variables based on scientific concepts and processes.

3) Take measurements in the field of variables

4) Conducting Graph Data Analysis and Understanding the Infiltration Process

5) Formulate scientific concepts and processes based on the results of data analysis and references

\section{B. Concept Design and Infiltration Science Process}

Designing material refers to the results of data analysis and references and Designing Explorative Worksheets

\section{Data Collection Techniques and Instruments}

The data collection technique used is Observation to directly observe land that will be used as a place of research and describe the focus found so that it can obtain data for research. The second data collection technique, namely documentation, is used to obtain additional information in the form of written sources, photographs to complete this study.

\section{Data Analysis Techniques}

The data analysis technique used in this study is qualitative analysis. Qualitative analysis according to Mile and Huberman as quoted by Salim (2006: 20-24) in Artike (2012) states that there are three steps for qualitative data processing, namely data reduction, data display, and conclusion drawing (conclusion drawing and verification). But researchers only limit to the second step.

\section{EXPERIMENT AND RESULT}

This research was carried out on June 13-19 2019. The research location was Manado State University (UNIMA) located on the Tonsaru hill, Tataaran Tondano. The research location can be seen in Figure 1 as follows:

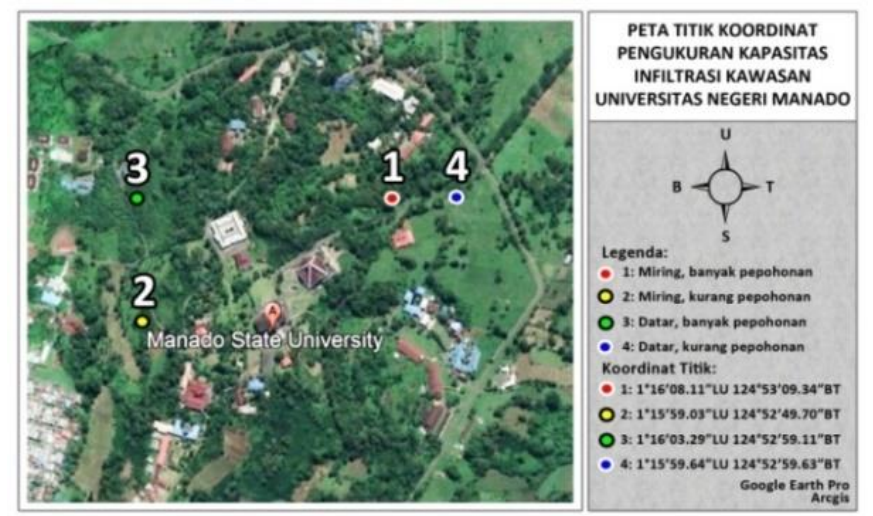

Figure 1. Research Location

\section{A. Description of Explorative Research Results in Infiltration}

1. Observation and Identification of Facts, Phenomena, and Relationships between Objects and Fact Phenomena.

1) Observation fact, Phenomenon and Relationship between Objects, in fact, phenomenon.

This observation was conducted in November 2018 at UNIMA together with lecturers and collaborative research teams. Researchers used observation sheets with item number 5 to determine the land to be a place of research

2) Identification of Facts, Phenomena, and Relationships between Objects and Facts, Phenomena.

Identification of fact, the phenomenon is made to specify which 4 locations as for all 4 locations as follows:

a) The location of the first study was in front of the workshop building at the coordinate point $1^{\circ}$ 16'08.11 "LU $124^{\circ} 53$ '09.34" BT. This location has a slope of ${ }^{250}$ and is dominated by tree-level and sapling plants, and has soil moisture of $30 \%$ and a soil $\mathrm{pH}$ of 6.3. The first location can be seen in Figure 2. 


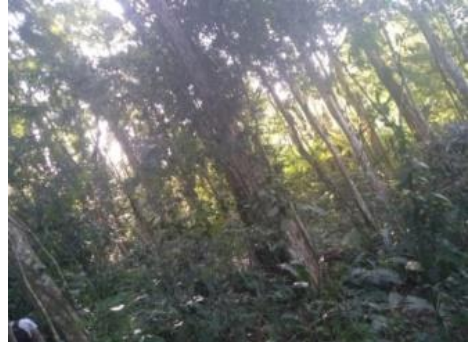

Figure $2.20^{\circ}$ sloping land lots of trees (in front of the workshop)

b) The location is the second study is on the path between the Faculty of Social Sciences (FIS) towards Faculty of Language and Arts (FBS) at coordinates $1{ }^{\circ} 15$ '59.03 'N 124

$52^{\prime} 49.70^{\prime \prime}$ E. This location has a slope of $10^{\circ}$ and is dominated by lower-level vegetation (grass). At this location, it has soil moisture of $20 \%$ and a soil $\mathrm{pH}$ of 6.8 . The second location can be seen in Figure 3.

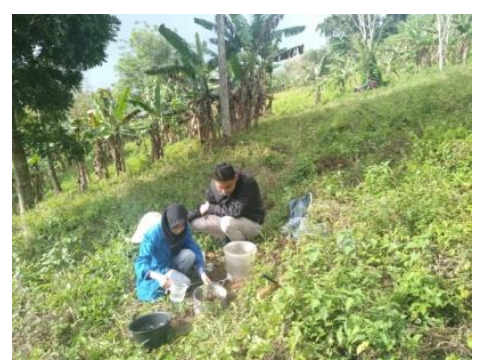

Figure 3. Land 3 flat a lot of trees (the direction of the Bidikmisi hostel)

c) The location of the third study is along the path towards the Bidikmisi UNIMA dormitory at the coordinate point $1^{\circ} 15^{\prime} 59.03$ "LU $124^{\circ} 52$ ' 49.70 ” East. This location has flat land dominated by vegetation at the sapling level and has soil moisture of $30 \%$ and a soil $\mathrm{pH}$ of 6.3 . The $3^{\text {rd }}$ location can be seen in Figure 4.

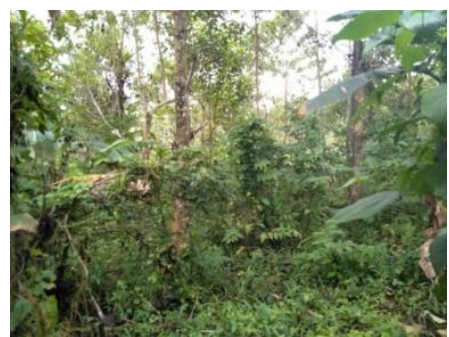

Figure 4. Land 3 flat lots of trees (towards Bidikmisi hostel)

d) The fourth location is next to the workshop building at the coordinate point $1^{\circ} 15^{\prime} 59.64$ "LU $124^{\circ} 52^{\prime} 59.63 "$ East. This location has flat land and is dominated by lower-level vegetation (grass). This location has soil moisture of $10 \%$ and a soil $\mathrm{pH}$ of 6 . The location can be seen in Figure 5.

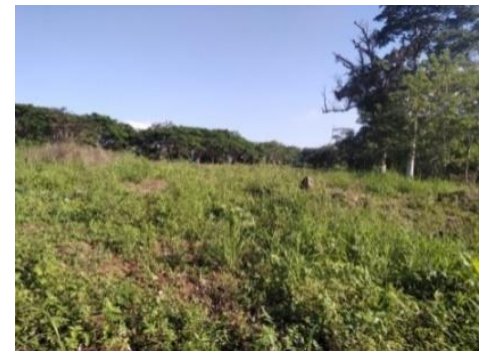

Figure 5 flat 4 fewer trees (next to the workshop)

2. Analyzing Phenomenon Facts

Analysis of facts and phenomena on infiltration according to several sources namely, infiltration, soil, humidity.

3. Checking the concept and process of science

4. Observe the phenomenon of the details of the components that interact to affect the phenomenon.

1) Components that are in the four fields:

a) The first research location has components in the form of:

- Coordinate point $1{ }^{\circ} 16^{\prime} 08.11$ "LU $124^{\circ} 53^{\prime} 09.34 "$ East

- Land slope $25^{\mathrm{O}}$

- Plant vegetation dominated by tree level and sapling level.

- Humidity n $30 \%$ soil and soil $\mathrm{pH}$ of 6.3

b) The second research location has components in the form of:

- Coordinate point $1{ }^{\circ} 15^{\prime} 59.03$ "LU $124{ }^{\circ} 52^{\prime} 49.70 "$ East

- Land slope $10^{\mathrm{O}}$

- Dominated by lower vegetation (grass)

- Soil humidity is $20 \%$ and soil $\mathrm{pH}$ is 6.8

c) The third research location has components in the form of:

- Coordinate point $1^{\circ} 15^{\prime} 59.03$ "LU $124{ }^{\circ} 52^{\prime} 49.70 "$ East.

- Dominated by sapling vegetation

- $30 \%$ of soil moisture and soil pH 6.3

d) The fourth research location has components in the form of:

- Coordinate Point $1{ }^{\circ} 15^{\prime} 59.64$ "LU 124 o 52'59.63" East

- Dominated by lower vegetation (grass)

- Very dense soil (clay)

- Soil moisture is $10 \%$ and soil $\mathrm{pH}$ is 6 
2) Identifying variables that affect phenomena and relationships between variables into scientific processes and concepts.

3) The results of measurements in the field against variables.

a) The first location of sloping land $25^{\circ}$ lots of trees.

The results of research conducted on sloping $25^{\circ}$ lots of trees with $30 \%$ humidity can be seen in Figure 6:

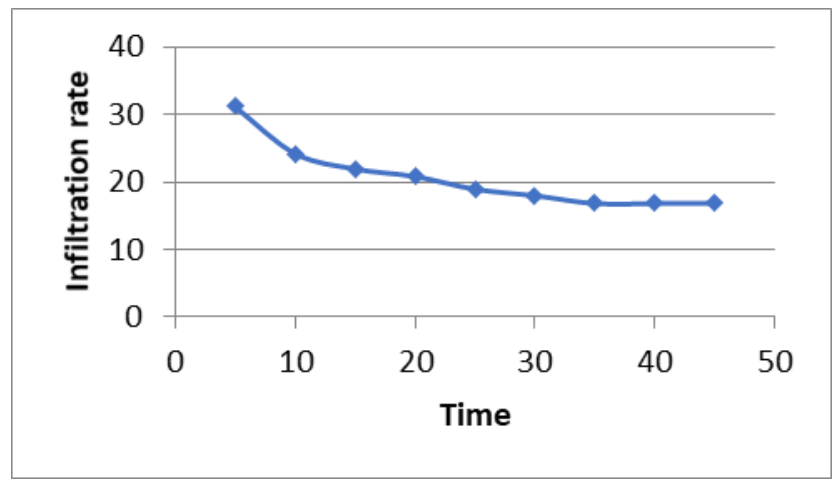

Figure 6. Infiltration Rate Curve in the First Land

The results obtained by using the method Horton where the value of the average infiltration rate ranges from $20: 59 \mathrm{~cm} / \mathrm{h}$ and the infiltration capacity of $16.8 \mathrm{~cm} /$ hour which included into the classification being (according to $U$. S Soil Conservation in (Harimi, 2018)). Thing is due to the condition of the soil at this very moist soil caused by leafy trees that cover the incoming sunlight to the ground. So that the soil tends to approach saturation. trees

a) The location of the two sloping lands is $10^{\circ}$ with a few

Research carried out on sloping lands $10^{\circ}$ little trees with humidity $20 \%$ can be seen in Figure 7.

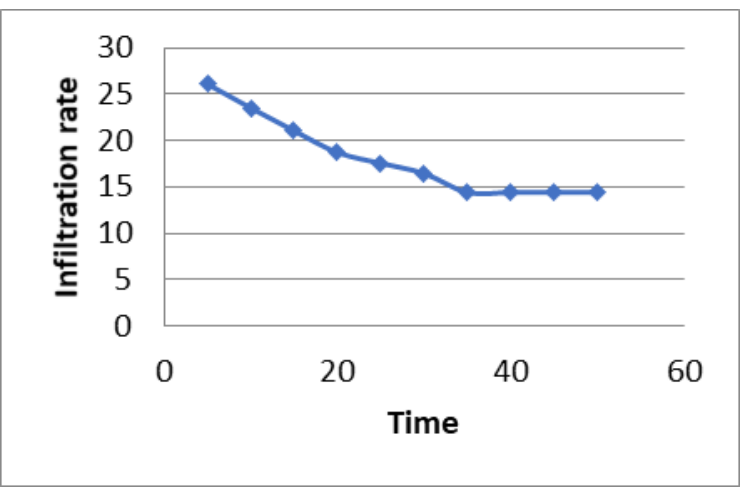

Figure 7. Infiltration Rate Curve in the Second Land

Based on calculations using the Horton method average infiltration rate amounted to $48.7 \mathrm{~cm} /$ hour and the infiltration capacity of $34.8 \mathrm{~cm} /$ hour including classification into a bit faster (by U.S Soil Conservation in (Harimi, 2018)). $\mathrm{H}$ al is because at the location of the sloping land $10^{\mathrm{O}}$ little trees dominated vegetation lower levels (grass) and has a lower moisture so that the soil tends to be very dry or the water content in the soil is so low that enables the roots to the grass tends to increase the rate of infiltration therefore at this location the infiltration is high.

b) The location of the three flat plots of trees

Results of research conducted on flat land with many trees humidity $30 \%$ can be seen in Figure 8 .

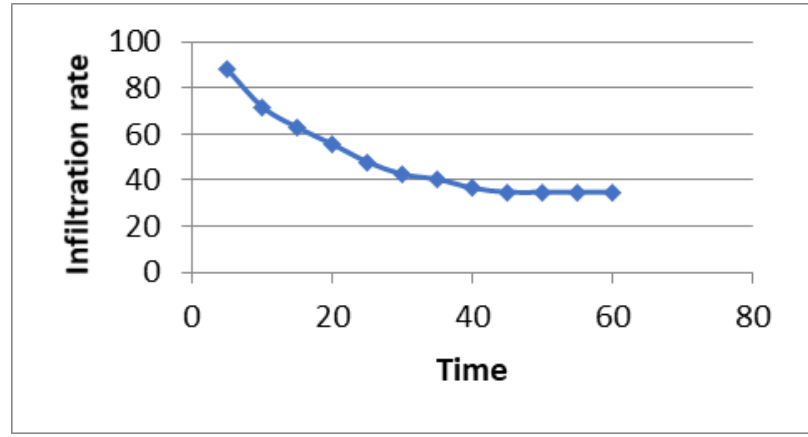

Figure 8. Infiltration rate curve at the third location.

Based on calculations using Horton, the average infiltration rate is $18.0 \mathrm{~km} / \mathrm{h}$ and the infiltration capacity of $14.4 \mathrm{~cm} /$ hour included in the classifications rather slow (according to $U$. $S$ Soil Conservation in (Harimi, 2018)). Due to the condition of the land that has high humidity and is affected by the lack of light entering the soil so that the soil has reached its saturation point.

c) Location of the four-flat land with a few trees.

The results of research conducted on flat land with few trees with a humidity of $10 \%$ can be seen in Figure 9.

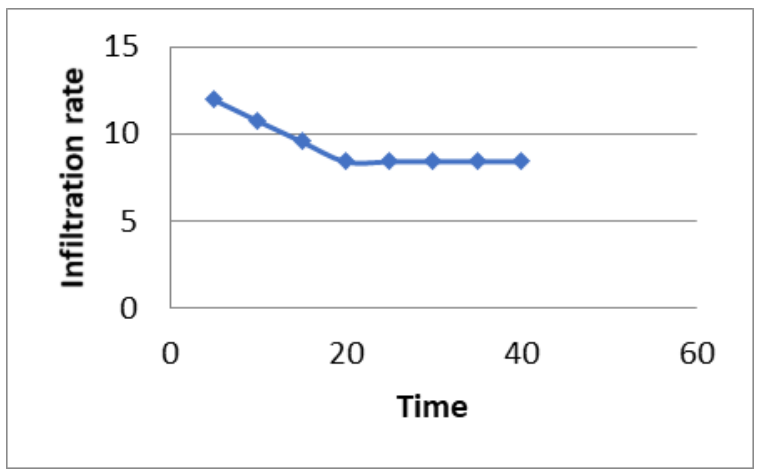

Figure 9. Infiltration Rate Curve at the fourth location

Based on calculations using Horton formula, the average number of infiltration rate of $9.3 \mathrm{~cm} /$ hour and the infiltration capacity of $8.4 \mathrm{~cm} /$ hour, or categorized slow (according to $U . S$ Soil Conservation in (Harimi, 2018)). Because on this land 
Published Online January 2020 in IJEAST (http://www.ijeast.com)

there is no trees vegetation and solid soil (clay soil) so that the infiltration rate is very small.

5. Conducting Graph Data Analysis and Understanding the Infiltration Process
Infiltration measurements were carried out at four different locations. The sum of the average values of infiltration rate and infiltration capacity at 4 different locations can be seen in table 1 .

\begin{tabular}{|c|c|c|c|}
\hline Measurement Location & $\begin{array}{l}\text { Average } \\
\text { Infiltration } \\
(\mathrm{Cm} / \text { Hour })\end{array}$ & $\begin{array}{l}\text { Infiltrati } \\
\text { on capacity } \\
(\mathrm{cm} / \text { hour })\end{array}$ & Information \\
\hline $\begin{array}{l}25^{0} \text { sloping land lots of trees (In } \\
\text { front of the workshop building at the } \\
\text { coordinates } 1^{\circ} 16^{\prime} 08.11 \text { "LU } 124{ }^{\circ} \\
53^{\prime} 09.34^{\prime \prime} \text { BT) }\end{array}$ & 20.59 & 16.8 & medium \\
\hline $\begin{array}{l}10^{0} \text { sloping lands with few trees } \\
\text { (The path between the Faculty of } \\
\text { Social and Political Sciences to FBS } \\
\text { at the coordinate point } 1^{\circ} 15^{\prime} 59.03 \\
\text { "LU } 124^{\circ} 52^{\prime} 49.70^{\prime} \text { BT) }\end{array}$ & 48.72 & 34.8 & Rather fast \\
\hline $\begin{array}{l}\text { Flatland with lots of trees (Path to } \\
\text { the Bidikmisi UNIMA boarding } \\
\text { house at the coordinate point } 1 \\
\left.15^{\prime} 59.03 \text { "N } 124^{\circ} 52^{\prime} 49.70^{\prime \prime} \mathrm{E}\right)\end{array}$ & 18.09 & 14.4 & A little slow \\
\hline $\begin{array}{l}\text { Flatland with little trees (Next to } \\
\text { the workshop building at the } \\
\text { coordinates) } 1 \text { o } 15^{\prime} 59.64 \text { "LU } 124^{\circ} \\
52^{\prime} 59.63 " \text { BT) }\end{array}$ & 9.27 & 8.4 & slow \\
\hline
\end{tabular}

Table 2. Explorative Infiltration Capacity

\begin{tabular}{|c|c|c|c|c|c|c|}
\hline \multirow[b]{2}{*}{$\begin{array}{l}\text { Facts, } \\
\text { phenomena }\end{array}$} & \multirow[b]{2}{*}{ Variable } & \multicolumn{3}{|c|}{ Related concept } & \multirow[b]{2}{*}{ Science process } & \multirow[b]{2}{*}{$\begin{array}{l}\text { Synthesis } \\
\text { analysis }\end{array}$} \\
\hline & & $\begin{array}{l}\text { Physics } \\
\text { Concept }\end{array}$ & $\begin{array}{r}\text { Biologic } \\
\text { al Concepts }\end{array}$ & $\begin{array}{l}\text { Chemi } \\
\text { cal } \\
\text { concept }\end{array}$ & & \\
\hline (1) & (2) & (3) & (4) & (5) & (6) & (7) \\
\hline
\end{tabular}


International Journal of Engineering Applied Sciences and Technology, 2020

Vol. 4, Issue 9, ISSN No. 2455-2143, Pages 435-443

Published Online January 2020 in IJEAST (http://www.ijeast.com)

\begin{tabular}{|c|c|c|c|c|c|c|}
\hline \multirow[t]{4}{*}{$\begin{array}{ll}\text { Water } & \text { rain } \\
\text { entered } & \text { into } \\
\text { the land } & \end{array}$} & $\begin{array}{l}\text { Pore surface } \\
\text { of the soil }\end{array}$ & $\begin{array}{l}\text { 1. Gravitational } \\
\text { force } \\
\text { 2. Kapiler Style }\end{array}$ & & $\begin{array}{l}\quad \text { Chemi } \\
\text { cal content } \\
\text { of } \\
\text { rainwater }\end{array}$ & $\begin{array}{l}\text { The process of entry } \\
\text { of water rain into the } \\
\text { soil through the pores of } \\
\text { the surface of the soil } \\
\text { and then affected by } \\
\text { force of gravity, water } \\
\text { rain flows straight into } \\
\text { the ground via the } \\
\text { profile soil. On the other } \\
\text { style, hood slobber is } \\
\text { streaming water upright } \\
\text { straight upwards, } \\
\text { downwards and towards } \\
\text { horizontal. }\end{array}$ & $\begin{array}{l}\text { - } F=G \frac{m 1 m 2}{r 2} \\
\text { - } F=m g \\
\text { - } y=\frac{z y \cos 0}{p \cdot g \cdot r} \\
\text { - Steam } \\
\quad \text { water or } \\
\text { H O, } \\
\text { acid } \\
\text { nitrate, } \\
\text { carbon, } \\
\text { acid } \\
\text { sulfate, } \\
\text { natrium }\end{array}$ \\
\hline & Splash of rain & $\begin{array}{l}\text { 1. Collision on } \\
\text { the ground } \\
\text { (P) } \\
\text { 2. Massa grain } \\
\text { rain }\left(\mathrm{m}_{\text {a) }} \text { and }\right. \\
\text { the mass of } \\
\text { grains ground } \\
\left(\mathrm{m}_{\mathrm{t}}\right)\end{array}$ & & & $\begin{array}{l}\text { When water rainfalls } \\
\text { occur splash water rain } \\
\text { which points water rain } \\
\text { has mass can release the } \\
\text { grain surface of the } \\
\text { ground that collides } \\
\text { directly with the ground } \\
\text { so that makes grain } \\
\text { surface of the ground } \\
\text { regardless. }\end{array}$ & $\begin{array}{c}\text { - Collision } \\
\text { (P) }\end{array}$ \\
\hline & rainfall rain & $\begin{array}{l}\text { 1. The } \\
\text { intensity of } \\
\text { sunlight } \\
\text { 2. Freefall } \\
\text { motion } \\
\text { 3. Gravitationa } \\
1 \text { force }\end{array}$ & Evaporation & $\begin{array}{l}\text { Heat } \\
\text { energy }\end{array}$ & $\begin{array}{l}\text { The light sun that } \\
\text { emitted produces } \\
\text { changes in the energy of } \\
\text { heat that can lead to the } \\
\text { evaporation of water so } \\
\text { of evaporation that } \\
\text { occurs events } \\
\text { condensation and by the } \\
\text { influence of the force of } \\
\text { gravity pouring rain the } \\
\text { surface soil. }\end{array}$ & $\begin{array}{l}I=\frac{\mathrm{F}}{\mathrm{w}} \\
\text { - } v t=g t \\
\text { - } F=G \frac{m 1 m 2}{r 2} \\
\text { - } F=m g\end{array}$ \\
\hline & & & & & & - $Q=m c \Delta T$ \\
\hline $\begin{array}{l}\text { Infiltratio } \\
n \text { of the } \\
\text { variation } \\
\text { slope of the } \\
\text { land lots of } \\
\text { trees }\end{array}$ & $\begin{array}{l}\text { 1. Tilt }(\alpha) \\
\text { 2.Plant } \\
\text { verification }\end{array}$ & $\begin{array}{l}\text { 1. Infiltration } \\
\text { 2. Gravity } \\
\text { 3. Capillary } \\
\text { style } \\
\text { 4. Sun } \\
\text { intensity } \\
\begin{array}{l}\text { 5. Soil } \\
\text { moisture }\end{array}\end{array}$ & $\begin{array}{l}\text { 1. Rooting } \\
\text { type } \\
\text { 2. Hydrology }\end{array}$ & soil $\mathrm{pH}$ & $\begin{array}{l}\text { In the infiltration } \\
\text { process on sloping land, } \\
\text { many trees have a } \\
\text { moderate infiltration rate } \\
\text { due to plant vegetation, } \\
\text { soil moisture and the } \\
\text { pull of gravity and } \\
\text { capillary forces. Where } \\
\text { style capillary makes } \\
\text { water rain that entry will } \\
\text { flow into every direction } \\
\text { including into roots of }\end{array}$ & 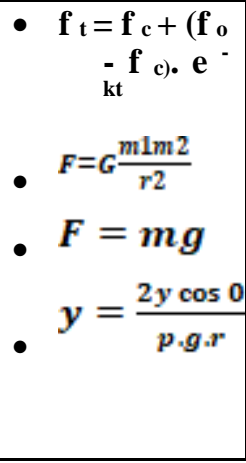 \\
\hline
\end{tabular}


International Journal of Engineering Applied Sciences and Technology, 2020

Vol. 4, Issue 9, ISSN No. 2455-2143, Pages 435-443

Published Online January 2020 in IJEAST (http://www.ijeast.com)

\begin{tabular}{|c|c|c|c|c|c|c|}
\hline & & & & & trees. & - $I=\frac{\mathrm{F}}{\mathrm{w}}$ \\
\hline $\begin{array}{l}\text { Infiltratio } \\
\mathrm{n} \text { in the slope } \\
\text { variations } \\
\text { fewer trees }\end{array}$ & $\begin{array}{ll}\text { 1. } & \text { Tilt }(\alpha) \\
\text { 2. } & \text { Not } \\
\text { there are } \\
\text { trees } \\
\text { were lush } \\
\text { 3. } & \text { Grass }\end{array}$ & $\begin{array}{l}\text { 1. Infiltration } \\
\text { 2. Graffiti on } \\
\text { sloping } \\
\text { land } \\
\text { 3. Capillary } \\
\text { style } \\
\text { 4. Humidity }\end{array}$ & $\begin{array}{l}\text { 1. Hydrology } \\
\text { 2. Types of } \\
\text { roots in } \\
\text { grass }\end{array}$ & soil pH & $\begin{array}{l}\text { The process of } \\
\text { infiltration on land } \\
\text { sloping fewer trees have } \\
\text { infiltration rather } \\
\text { quickly, where p } \\
\text { Increased potential } \\
\text { capillary is together with } \\
\text { gravity will accelerate } \\
\text { infiltration if a shortage } \\
\text { of moisture soil. Also, } \\
\text { the infiltration rate on } \\
\text { this land is influenced } \\
\text { by the amount of grass } \\
\text { that tends to increase } \\
\text { water infiltration into } \\
\text { the soil. }\end{array}$ & 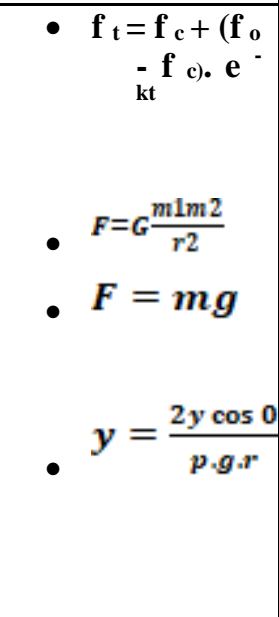 \\
\hline \begin{tabular}{l}
\multicolumn{2}{c}{ Infiltratio } \\
$\mathrm{n}$ in the \\
Variation of \\
flat land in \\
many trees
\end{tabular} & Vegetations & $\begin{array}{l}\text { 1. Infiltration } \\
\text { 2. Gravitationa } \\
\text { 1 force } \\
\text { 3. Capillary } \\
\text { style } \\
\text { 4. The } \\
\text { intensity of } \\
\text { sunlight } \\
\text { 5. Soil } \\
\text { moisture. }\end{array}$ & $\begin{array}{l}\text { 1. Hydrology } \\
\text { 2. Rooting } \\
\text { type }\end{array}$ & soil pH & $\begin{array}{l}\text { On land flat lots of } \\
\text { trees light of the sun will } \\
\text { be less entered into the } \\
\text { case is due to the canopy } \\
\text { on plants that inhibit } \\
\text { light entrance so that the } \\
\text { condition of the soil } \\
\text { becomes wet case this } \\
\text { resulted in the rate of } \\
\text { infiltration in the area is } \\
\text { classified as a bit slow. } \\
\text { Style capillary makes } \\
\text { the water will enter into } \\
\text { the roots of plants into } \\
\text { the soil allows water } \\
\text { will continue to enter } \\
\text { into the ground. }\end{array}$ & 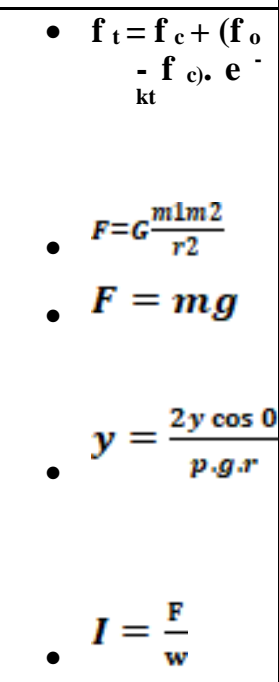 \\
\hline \begin{tabular}{l}
\multicolumn{2}{c}{ Infiltratio } \\
$\mathrm{n}$ in the \\
Variation of \\
flat land with \\
fewer trees
\end{tabular} & $\begin{array}{l}\text { Not there is } \\
\text { vegetation } \\
\text { plant }\end{array}$ & $\begin{array}{l}\text { 1. infiltration } \\
\text { 2. Style } \\
\text { gravity } \\
\text { 3. Capillary } \\
\text { style } \\
\text { 4. Humidity }\end{array}$ & Hydrology & soil $\mathrm{pH}$ & $\begin{array}{l}\text { The infiltration } \\
\text { process on flat land with } \\
\text { fewer trees has a slow or } \\
\text { small infiltration rate } \\
\text { due to dense soil types, } \\
\text { resulting in a small } \\
\text { infiltration rate. } \\
\qquad y=y\end{array}$ & 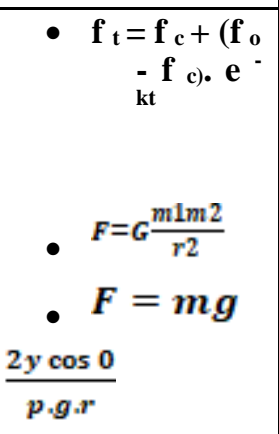 \\
\hline \begin{tabular}{l}
\multicolumn{2}{c}{ Stagnant } \\
water on the \\
flat land \\
surface
\end{tabular} & $\begin{array}{l}\text { The motion of } \\
\text { objects on a } \\
\text { flat surface }\end{array}$ & $\begin{array}{l}\text { Gravitational } \\
\text { Force }\end{array}$ & & & $\begin{array}{l}\text { On the surface of the } \\
\text { land flat if it happens } \\
\text { rain profusely on the } \\
\text { land flat will occur } \\
\text { puddle of water. } \\
\text { Puddles of water }\end{array}$ & $\begin{array}{l}\text { - } F=G \frac{m 1 m L}{r^{2}} \\
\text { - } F=m g\end{array}$ \\
\hline
\end{tabular}




\begin{tabular}{|l|l|l|l|l|}
\hline & & & & \\
& & $\begin{array}{l}\text { caused by the soil that } \\
\text { had reached the point of } \\
\text { saturation so that water } \\
\text { is not able enter again } \\
\text { into the soil so it } \\
\text { happened puddle of } \\
\text { water on the surface of } \\
\text { the land flat. }\end{array}$ \\
\hline
\end{tabular}

From table 1 shows that the sloping land $25^{\circ}$ many trees have an average infiltration rate of $20.59 \mathrm{~cm} / \mathrm{hr}$ and the infiltration capacity of $16.8 \mathrm{~cm} /$ hour or included in the category of being this is because the condition of the soil in this area has high humidity. After all, this location is dominated by treelevel vegetation and sapling levels which result in sunlight being unable to penetrate the soil surface. Instead slopes $10^{\circ}$ few trees had average infiltration rate of $48.72 \mathrm{~cm} / \mathrm{hr}$ and the infiltration capacity of $34.8 \mathrm{~cm} /$ hour included into the category rather quickly this is because at the location of the sloping land $10^{\mathrm{O}}$ little trees dominated vegetation lower levels (grass) and has a low humidity so that the soil tends to be very dry or the water content in the soil is very low so that the roots in the grass tend to increase the infiltration rate therefore at this location the infiltration is relatively high.

Besides that, on flat land, many trees have an average infiltration rate of $18.09 \mathrm{~cm} /$ hour and infiltration capacity of $14.4 \mathrm{~cm} /$ hour belong to the category of rather slow, because at this location rainwater will enter very slowly into the ground due to the condition of the land which has high humidity and influenced by the lack of light entering the ground. However, in this land-water continues to come in because at this location there are lush trees which cause the water will continue to seep into the ground until the soil experiences a saturation point and causes puddles on flat land. While flat land with few trees has an average infiltration rate of $9.27 \mathrm{~cm} /$ hour and infiltration capacity of $8.4 \mathrm{~cm} /$ hour is included in the slow category, because on this land there is no trees vegetation and dense soil (clay) so the infiltration rate is very small.

Of the four research sites have different infiltration values and infiltration capacity, where land that has low humidity or low soil water content, and has solid trees/grasses tend to increase the infiltration rate so that it falls into the medium and rather fast category. Whereas on land that has dense soil texture (clay) is included in the slow category. And on flat land puddles will occur on the surface of the soil if it reaches a saturation point.

6. Formulate Concepts and Networks of Science Process Concepts Based on Data Analysis and Reference Results.

Result formulate concepts and networking concepts science process based on data analysis and references presented in the form of a matrix. There are 6 facts and phenomena related to infiltration and reported with existing scientific concepts, where the first facts and phenomena, rainwater enters the ground, the second fact and phenomenon of infiltration in the variation of land slope of many trees, facts and phenomena to three infiltrations in the variation of the slope is fewer trees infiltration in the miscellany of the slope is fewer trees, facts, and phenomena to infiltration place on a variety of flat land many trees, facts and phenomena to five infiltration on a variety of flat land less than the trees and the fact that all six puddles on a flat surface.

\section{B. Description of the Concept Design and Infiltration Science Process}

The results of research exploring the concepts and processes of science can be utilized as a theoretical reference in soil science in the form of materials and worksheets that can be used during the learning process and practicum.

The results of the study explored infiltration measurements on all four fields using an infiltrometer. The results of shaving from the four fields there are significant differences.

On sloping land $25^{\circ}$ many trees have an average infiltration rate of $20.59 \mathrm{~cm} /$ day and the infiltration capacity of $16.8 \mathrm{~cm} /$ hour, with moisture contents of $30 \%$ caused by density of trees, resulting in sunlight cannot penetrate the soil so that the soil surface so moist and resulting in the infiltration rate is classified as this is in line with the statement (Aidatul, 2015) which states the more humid conditions of a soil, the rate of infiltration decreases because the land is getting closer to saturation.

There are slopes $10^{\circ}$ few trees had average infiltration rate of $48.72 \mathrm{~cm} / \mathrm{h}$ and infiltration capacity of $34.8 \mathrm{~cm} /$ hour has a humidity of $20 \%$ were classified as dry, resulting in the infiltration rate increases in line with the research Wisler and Brater (1959) in Wibowo (2014) this effect can be shown if the soil is dry enough, then wetting the top layer and the gravitational force causes high water potential differences so as not to increase the infiltration rate other than that this land is dominated by lower-level vegetation (grass) which results in rooting in the grass increasing the infiltration rate, this is in line with the results of the study. (Yunagardasari et al., 2017) states that where roots in the vegetation of grass can help the process of water entering the soil because the movement of the roots will progressively go downward, forming cavities in the soil where water can pass through and the roots will bind water for their own needs, thus increasing the rate of infiltration. This is a factor influencing the high infiltration rate compared to the three fields.

There is no flat land many trees have the infiltration rate of 18:09 $\mathrm{cm} /$ day and the infiltration capacity of 14.4 $\mathrm{cm} /$ hour it is caused by leafy trees that cover the incoming sunlight to soil surface so that the soil has humidity by $30 \%$, in 
line with the research Wibowo (2014) where infiltration is influenced by soil moisture (water content conditions) on the land. High conditions of water content in a soil cause faster achievement of the minimum infiltration rate

The infiltration rate is slow on flat plots of trees with an average infiltration rate of $9.27 \mathrm{~cm} /$ hour and infiltration capacity of $8.4 \mathrm{~cm} /$ hour including this because the land has dense land (clay) so the infiltration rate is very small. This is a factor that influences the rate of small infiltration.

This is in agreement with Harimi's research (2018), for the same type of soil with different densities having different infiltration rates, the denser the smaller the infiltration rate.

From the four fields, it can be seen that several factors influence the rate of infiltration and infiltration capacity, including factors of plant vegetation, soil moisture, and soil density. Flatland will occur inundation if it reaches a saturation point or the intensity of rain exceeds the infiltration capacity. This is in line with the statement of Hanks \& Ashcroft (1986) in Aidatul (2015). If the intensity of the rain exceeds the capacity of infiltration, then there is a surface runoff that can cause puddles

The results of research explore the facts that exist in infiltration that can be linked to scientific concepts and processes and presented in the form of a matrix. Also, researchers designed the concepts and scientific processes and made a material related to infiltration and a description of the concepts that exist in infiltration and worksheets that use 3 explorative procedures which will later become a reference in the learning process and practicum in the subjects of soil science.

\section{CONCLUSION}

Based on the results and discussion of infiltration capacity in several fields of the State University of Manado that: The concepts and processes of science in infiltration include physics (Gravitational force, capillary force, collision on the ground, mass of rain grains and grain mass of soil, light intensity, free-fall motion, soil moisture ), chemistry (chemical content of rainwater, heat energy, soil pH), biology (evaporation, root type, hydrology) and presented in the form of matrices and concept designs and infiltration science processes in the form of materials and worksheets and can be used as reference lectures in the eyes college of soil science.

\section{REFERENCE}

Aidatul N,. (2015) . Pemetaan Laju Infiltrasi Menggunakan Metode Horton Di Sub Das Tenggarang Kabupaten Bondowoso .Jember. Fakultas Teknik Universitas Jember. (hal 7-9)

Artike, K. 2012 III METODOLOGI PENELITIAN (Online) http://digilib.unila.ac.id/1615/7/BAB\%20III\%20.pdf. 12 Februari 2019. (hal 52)
Fitriani, L.2016. Evaluasi Pemanfaatan Lahan Di Kecamatan Rembang Kabupaten Purbalingga. Purwokerto : FKIP UMP. (hal 8)

Harimi N,. (2018). Pengaruh Tipe Vegetasi Tumbuhan Terhadap Laju Infiltrasi Di Kawasan Geothermalie Suum Kecamatan Mesjid Raya Kabupaten Aceh Besar Sebagai Referensi Matakuliah Ekologi Tumbuhan. Banda Aceh. Fakultas Tarbiyah Universitas Islam Negeri Ar-Raniry. (hal 20-28)

Irawan T,. (2016). Infiltrasi Pada Berbagai Tegakan Hutan Di Arboretum Universitas Lampung. Bandar Lampung : FP Universita Negeri Lampung. (hal 7-15)

Jaedun, A. (2018). Metode Penelitian. (Online) http://staffnew.uny.ac.id/upload/131569339/pendidikan 12 Metode+Penelitian.pptx. Di akses 15 Desember 2018.

Medellu Ch. S., dan Silangen P. M. 2019. Konteks Budaya Dalam Pembelajaran Fisika. Artikel dilindungi sebagai KI no: 000154191, tanggal 16 juli 2019.

Notohadiprawiro, T. (2006). Kemampuan dan kesesuaian lahan : pengertian dan penetapannya. http://soil.blog.ugm.ac.id/files/2006/11/1991-

Kemampuan-dan1.pdf. Di akses 6 mei 2019.

Sondakh D.,dkk. (2015). Aplikasi Peta 3-Dimensi Universitas Negeri Manado. Universita Klabat, 814. https://media.neliti.com/media/publications/171277-IDaplikasi-peta-3-dimensi-universitas-nege.pdf. Di akses 12 Februari 2019.

Sulastriningsih, S,. (2011). Hidrologi.Yogyakarta : Atlantis.(hal 13)

Wibowo, C.A. (2014). Pengaruh Kelembaban Tanah Terhadap Waktu Pencapaian Kapasitas Infiltrasi Di Berbagai Penggunaan Lahan. Bogor Fakultas Pertanian Institut Pertanian Bogor Bogor. (hal 4-7)

Yunagardasari, dkk. (2017). Model Infiltrasi Pada Berbagai Penggunaan Lahan di Desa Tulo kecamatan Dolo Kabupaten Sigi. Universitas Tadulako. Palu. 320, (hal 315-323).

http://jurnal.untad.ac.id/jurnal/index.php/Agrotekbis/art icle/view/10140. Accessed 1st june 2019 